\title{
PERBANDINGAN HASIL BELAJAR PESERTA DIDIK ALUMNI SMP DAN MTS DALAM MATA PELAJARAN BAHASA ARAB KELAS X DI SMA NEGERI 1 PALU
}

\author{
Ahmad Asse, Kartika Kirana Lestari
}

Institut Agama Islam Negeri Palu, Indonesia

Jl. Diponegoro No. 23, Kec: Palu Barat, Kota Palu, Sulawesi Tengah, 94221, Indonesia Corresponding E-mail: asseahmadpba@gmail.com

\section{Abstrak}

Penelitian ini bertujuan untuk mengetahui perbandingan hasi belajar antara peserta didik alumni SMP dengan peserta didik alumni MTs dalam mata pelajaran bahasa Arab kelas $X$ di SMA Negeri 1 Palu. Penelitian ini menggunakan pendekatan metode kuantitatif dengan rancangan penelitian judul komparatif.

Dalam penelitian ini, terdapat dua populasi yaitu populasi 1 terdiri dari peserta didik alumni SMP kelas X IPS dan X Bahasa SMA Negeri 1 Palu, dan populasi 2 adalah peserta didik alumni MTs kelas X IPS dan X Bahasa SMA Negeri 1 Palu. Teknik pengambilan sampel yang digunakan adalah Proportionate Stratified Random Sampling untuk peserta didik alumni SMP dan teknik sampel jenuh untuk peserta didik alumni MTs. Dengan jumlah sampel yang terpilih 41 peserta didik alumni SMP dan 12 peserta didik alumni MTs.

Teknik pengumpulan data melalui teknik observasi, dokumentasi, dan wawancara. Kemudian teknik analisis yang digunakan adalah analisis statistik deskriptif dan inferensial, yaitu Two Independent Samples Tests. Pengujian penelitian dengan uji Mann-Whitney.

Hasil olahan statistik yang dibantu dengan program program IBM SPSS Statictics 21 menunjukkan bahwa tidak terdapat perbedaan hasil belajar antara peserta didik alumni SMP dengan peserta didik alumni MTs dalam mata pelajaran Bahasa Arab kelas X IPS dan X Bahasa di SMA Negeri 1 Palu. Dengan nilai probabilitas (sig) $>0,05(0,856>0,05)$. Adapun latar belakang pendidikan, tidak memiliki pengaruh yang signifikan terhadap hasil belajar bahasa Arab , karena terdapat faktor lain yang mempengaruhi, diantaranya faktor eksternal dan internal berupa inteligensi, sikap, minat, teman maupun guru.

Kata kunci: Perbandingan, kuantitatif, Proportionate Stratified Random Sampling, observasi, inferensial, Mann Whitney

$$
\text { ملخص الدراسة }
$$




$$
\begin{aligned}
& \text { وكان في هذا البحث سكانيان وهما طلاب الفصل العاشر اللغوي من المدرسة العالية الحكومية } 1 \text { بالو، } \\
& \text { المتخرجون من المدرسة الثناوية الحكومية ومنالمدرسة الثناوية الإسلامية. والعينة المأخوذة هي واحد وأربعون } \\
& \text { طلابا متخرجين من الثناوية الحكومية واثنا عشرة طلابا متخرجين من الثناوية الإسلامية. }
\end{aligned}
$$

وأما طريقة استيفاء البيانات هي الملاحظة والتوثيق والمقابلة، ثم تحليلها بطريقة الاحصائية الوصفية

والنتيجئية أي two independent simple test، وطريقة تدقيق البحث كان باستخدام نظرية Mann Whitney.

وتقرير الإحصائي يدل على عدم الفرق بينهما مع قدر الاحتمالي (0,856) 0,05) 0,05) > (sig). بمعنى أن خلفية

التربية لا تؤثر إلى حاصل تعليم اللغة العربية لدى الطلاب، لأن فيه عوامل أخرى تؤثر في نجاح تعليم نحو عامل الذكاء، والموقف، والرغبة، والأصدقاء، والمعلم.

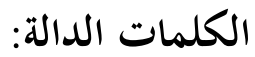

$$
\text { حاصل تعليم اللغة العربية، المدرسة، التوثيق، الاحصائية، عوامل }
$$

\section{A. Pendahuluan}

Bahasa Arab dikenal dengan sebutan bahasanya umat Islam. Hal ini dikarenakan, seluruh ajarannya yang tertuang dalam kitab suci yakni AlQur'an diturunkan dengan menggunakan bahasa Arab. Sebagaimana firman Allah dalam Q.S. Yusuf (12): 2 yang berbunyi:

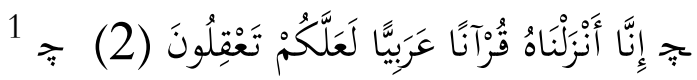

Terjemahan:

"Sesungguhnya Kami menurunkannya berupa Quran berbahasa Arab agar kamu mengerti".

$$
\text { Nabi yang membawa }
$$

kesempurnaan dalam kejayaan islam, nabi

\footnotetext{
${ }^{1}$ Al-Quran surah Yusuf: 2
}

yang kelak akan memberi syafaat pada umat Islam dihari perhitungan (yaumul mizan) kelak, serta nabi yang menutup garis kenabian karena merupakan nabi yang terakhir didunia, yakni nabi Muhammad saw, yang juga menggunakan bahasa Arab semasa hidupnya, dengan bekal inilah maka tidak heran mengapa bahasa Arab dikenal dengan bahasanya umat islam.

Sementara itu bahasa Arab adalah bahasa resmi dilebih dari 20 negara sekaligus menjadi bahasa ibu bagi lebih dari 300 juta orang.

Bahasa arab diucapkan di seluruh timur tengah, dari Maroko sampai ke Irak.

\footnotetext{
${ }^{2}$ Ahmad Qosim, Jurus Hebat Menguasai Percakapan Bahasa Arab Modern, (cet. II; Depok: PT. Palapa Alta Utama, 2015), v.
} 
Selain itu, karena bahasa Arab adalah bahasa Al-Qur'an dan Islam, maka bahasa ini dipahami oleh lebih dari 1,2 milyar orang di seluruh dunia. Sebagai efek geopolitik, bahasa Arab masuk dalam daftar bahasa penting didunia. Bahkan di Negara-negara di mana bahasa Arab tidak menjadi bahasa resmi, orang berlomba menguasai bahasa ini karena dianggap penting sebagai bahasa global. ${ }^{2}$

Inilah alasan mengapa bahasa Arab dijadikan sebagai salah satu bahasa tetap dan resmi di organisasi Perserikatan Bangsa-Bangsa (PBB) serta menduduki posisi setelah bahasa Spanyol. ${ }^{3}$

Adapun dalam dunia pendidikan khususnya di Indonesia, bahasa Arab kurang diminati oleh para peserta didik baik di madrasah maupun sekolahsekolah umum. Sebagaimana riset dalam sebuah jurnal Pendidikan Bahasa Arab dan Kebahasaaraban yang menyatakan bahwa, dalam perspektif siswa madrasah, faktor eksternal yang dapat menyebabkan demotivasi adalah karakteristik bahasa Arab, materi dan metodologi pembelajaran, lingkungan dan fasilitas belajar dan perilaku guru. Sedangkan

${ }^{3}$ Zulhannan, Teknik Pembelajaran Bahasa Arab, (Jakarta: Rajawali Pers, 2015), 4.

${ }^{4}$ Asep Muhammad Saepul Islam. "Faktor Demotivasi Pembelajaran Bahasa Arab Dalam Perspektif Siswa Madrasah". Jurnal Pendidikan Bahasa Arab dan

Kebahasaaraban, vol. 2, no.1 (30 Juni faktor internal pemicu demotivasi lebih banyak bersumber dari kemampuan dasar siswa dan pengalaman belajar sebelumnya dan juga sikap negatif siswa terhadap bahasa Arab. ${ }^{4}$

Berdasarkan riset tersebut, bahwa faktor kemampuan dasar siswa dan pengalaman belajar sebelumnya menjadi salah satu faktor hilangnya motivasi siswa sekolah umum maupun madrasah dalam mempelajari bahasa Arab. Hal ini juga dikarenakan kurangnya pembiasaan ataupun kurangnya kesadaran akan pentingnya bahasa Arab, bahkan telah terbangun paradigma yang keliru dalam pola pikir mereka atas rasa takut terhadap bahasa Arab itu sendiri, sehingga dalam mempelajarinya terasa sangat sulit.

Hal ini berbeda dengan para santri yang berada di pesantren. Dengan kehadiran pesantren memberikan ciri baru yang kental dengan bahasa Arab yang memberikan ciri khas pada pesantren. Setiap kita mendengar kata pesantren pasti yang pertama ada dibenak kita adalah sosok bahasa Arab yang membuatnya menjadi unik. ${ }^{5}$ Karena memang dilingkungan pesantren yang

2015). h. 13.

http://journal.uinjkt.ac.id/index.php/arabiyat/ article/view/1511 (diakses 14 November 2019).

5 Ismail Baharuddin, "Pesantren dan Bahasa Arab". Jurnal Thariqah Ilmiah, vol. 01, no. 01 (Januari 2014). h.29.http://jurnal.iainpadangsidimpuan.ac.id/index.php/TI/article/ view/253/0 (diakses 13 November 2019). 
notabene menggunakan bahasa Arab dalam keseharian para santri, sehingga menjadi tidak asing dan terasa mudah untuk dipelajari maupun untuk dipahami. Hal ini sejalan dengan perkataan Imam الخير Netyaningsih) kebaikan itu hanyalah kebiasaan. ${ }^{6}$

Kasus seperti diatas banyak terjadi dalam dunia pendidikan formal diberbagai jenjang pendidikan baik tingkat sekolah dasar SD/MI, menengah pertama SMP/MTs, maupun menengah atas SMA/MA. Akan tetapi mulai sangat dirasakan pada tingkat SMA dikarenakan pada tingkatan ini para peserta didik yang lulus dari SMP merasa sedikit asing dengan pembelajaran bahasa Arab yang ada di SMA. Hal ini lumrah terjadi karena di SMP tidak ada pembelajaran bahasa Arab didalamnya sesuai dengan kurikulum yang digunakan pada saat ini, sedangkan di MTs bahasa Arab harus diajarkan didalamnya karena memang sudah tertuang didalam kurikulum yang ada yakni 2 jam mata pelajaran setiap minggunya. Berdasarkan asumsi-asumsi inilah, menjadikan indikasi bahwa latar belakang pendidikan atau asal sekolah

\footnotetext{
${ }^{6}$ Agus Setyaningsih. "Prestasi Belajar Bahasa Arab Di Mts Ma'arif Nu 04 Tamansari Purbalingga (Studi komparasi siswa alumni MI dengan SD)".
}

memiliki peranan tertentu dalam menentukan hasil belajar peserta didik.

Adapun dengan lulusan SD dan MI yang melanjutkan pendidikannya di MTs, mereka tidak merasakan keasingan seperti lulusan SMP yang melanjutkan pendidikannya di SMA/MA. pada tingkatan MTs pembelajaran bahasa Arab yang diperoleh lulusan MI tidak jauh berbeda dengan mereka yang lulusan SD karena pembelajaran bahasa Arab tingkatan ini memang masih sangat sederhana sehingga setelah duduk dibangku MTs peserta didik alumni SD mampu menyelaraskan ataupun mengejar keteringgalannya pada mata pelajaran ini.

Yang menjadi fokus pada penelitian ini yaitu peserta didik alumni SMP dan MTs yang notabene memiliki perbedaan bekal pembelajaran bahasa Arab yang kemudian masuk ke SMA dan didalamnya terdapat pembelajaran bahasa Arab, sementara kita ketahui bersama bahwa pada tingkat SMA pembelajaran bahasa Arabnya tidak lagi meliputi dasardasar akan tetapi merupakan pembelajaran bahasa Arab lanjutan, ini akan terasa sangat sulit bagi mereka yang merupakan alumni SMP dan baru pertama kali mempelajarinya, kalaupun mereka muslim mungkin akan dimudahkan (diakses 22 Mei 2019). 
dengan bekal mengetahui huruf-huruf hijaiyah, bagaimana dengan mereka yang non muslim? Sudah jelas kesulitan yang mereka rasakan berlipat ganda dari peserta didik muslim karena harus mempelajari huruf-huruf terlebih dahulu. Adapun peserta didik alumni MTs mereka tentunya sudah tidak asing lagi, karena memang pembelajaran bahasa Arab yang telah mereka peroleh sejak duduk dibangku MTs dilanjutkan pada tingkatan ini. Hal inilah yang membuat penulis tertarik untuk melakukan penelitian dan mengkaji lebih dalam mengenai perbedaan hasil belajar peserta didik alumni SMP dan MTs di SMA Negeri 1 Palu.

Berdasarkan latar belakang yang telah diuraikan di atas, maka fokus permasalahan yang akan dicari jawabannya melalui penelitian ini dirumuskan sebagai berikut: "Bagaimana perbandingan hasil belajar peserta didik alumni SMP dan MTs dalam mata pelajaran bahasa Arab kelas X di SMA Negeri 1 Palu?".

Dari pokok masalah tersebut, penulis mengemukakan beberapa sub permasalahan yang dijadikan sebagai batasan masalah yakni sebagai berikut:

1. Apakah terdapat perbedaan yang signifikan terhadap hasil belajar peserta didik alumni SMP dan MTs dalam mata pelajaran bahasa Arab kelas X IPS dan Bahasa di SMA Negeri 1 Palu?

\section{Apakah hasil belajar bahasa Arab} peserta didik alumni MTs lebih baik daripada hasil belajar peserta didik alumni SMP?

Dengan adanya penelitian ini, diharapkan dapat memberikan sumbangsih keilmuan bagi pembaca serta sebagai tambahan referensi kepustakaan terkait perbandingan hasil belajar bahasa Arab peserta didik antara alumni SMP dengan siswa alumni MTs. Dan semoga karya ilmiah ini dapat pula memberikan sumbangan pemikiran bagi pengembangan ilmu pengetahuan serta bisa dijadikan pedoman dan pertimbangan bagi peneliti sejenis di masa mendatang.

Dilain sisi penulis berharap agar karya ilmiah ini dapat memberikan informasi kepada sekolah, guru, siswa dan orang tua tentang pencapaian prestasi belajar dalam pembelajaran bahasa Arab.

\section{B. Metode Penelitian}

\section{a. Pendekatan dan Desain Penelitian}

1. Pendekatan Penelitian

Penelitian merupakan suatu

kegiatan atau proses yang dilakukan dalam rangka membuktian atau memecahkan suatu persoalan dengan 
Al Bariq : Jurnal Pendidikan Bahasa Arab, 1, (1), 2020, 34-51

menggunakan metode ilmiah, sehingga dengan adanya penelitian kita dapat memperoleh hasil yang akurat dan terpercaya karena telah melalui tahapantahapan sistematis yang disebut dengan penelitian. Melalui sebuah penelitianlah terlahir banyak ide-ide, gagasan-gagasan serta temuan-temuan dari para ahli/peneliti terdahulu yang banyak kita jumpai dan kita gunakan hingga saat ini, bahkan kita lakukan penelitian kembali terhadap persoalan yang sama.

Pendekatan penelitian yang digunakan dalam penelitian ini adalah pendekatan penelitian kuantitatif yakni penelitian yang menghasilkan penemuanpenemuan yang dapat dicapai (diperoleh) dengan menggunakan prosedur-prosedur statistik atau cara-cara lain dari kuantifikasi (pengukuran). Pendekatan kuantitatif memusatkan perhatian pada gejala-gejala yang mempunyai karakteristik tertentu didalam kehidupan

${ }^{7}$ V. Wiratna Sujarweni, Metodologi Penelitian, (Yogyakarta: Pustaka Baru Press, 2014), 39. manusia yang dinamakannya sebagai variabel. Dalam pendekatan kuantitatif hakekat hubungan diantara variabelvariabel dianalisis dengan menggunakan teori yang obyektif. $^{7} \quad$ Sehingga menghasilkan teori yang kuat, yang probabilitas kebenaran dan toleransi kesalahannya dapat diperhitungkan, kebenaran teori yang dihasilkan selalu terbuka untuk diuji kembali, analisis yang dilakukan atas angka menghindarkan unsur subjektivitas. ${ }^{8}$

Berdasarkan pernyataan diatas sehingga dapat dipastikan bahwa penelitian ini menggunakan pendekatan kuantitatif, karena data yang disajikan adalah data hasil belajar peserta didik yaitu berupa nilai dalam bentuk angkaangka yang digunakan dalam proses menentukan, mengelola, dan menjabarkan hasil dari penelitian.

2. Desain Penelitian
${ }^{8}$ Andi Prastowo, Memahami Metode-Metode Penelitian, (Jogjakarta: Ar-Ruzz Media, 2014), 54. 
Al Bariq : Jurnal Pendidikan Bahasa Arab, 1, (1), 2020, 34-51

Rancangan dalam penelitian ini

yaitu menggunakan penelitian komparatif, yaitu penelitian yang ditujukan untuk melihat atau mengetahui perbandingan atau perbedaan mengenai kondisi (variabel) dari dua kelompok atau dua kurun waktu yang berbeda. ${ }^{9}$ Penelitian ini dimaksudkan untuk mengetahui adakah perbedaan hasil belajar mata pelajaran bahasa Arab antara peserta didik alumni SMP dan peserta didik alumni MTs di kelas X SMA Negeri 1 Palu atau adakah perbandingan antara variabel terikat (dependen) yang dipengaruhi oleh variabel bebas (independent). Variabel bebas (variabel $\mathrm{X}$ ) dalam penelitian ini ada dua kelompok yaitu peserta didik alumni SMP dan peserta didik alumni MTs dimana variabel ini yang dapat mempengaruhi, sedangkan variabel terikat (variabel Y) yakni hasil belajar bahasa Arab, merupakan variabel yang dipengaruhi.

\section{b. Populasi dan Sampel Penelitian}

\footnotetext{
${ }^{9}$ Widodo, Cerdik Menyusun Proposal Penelitian Skripsi, Tesis dan Disertasi, (Jakarta: Yayasan Kelopak dan Magna Script, 2005), 47.

${ }^{10}$ V. Wiratna Sujarweni, Metodologi Penelitian, 39.
}

1. Populasi

Populasi adalah keseluruhan jumlah yang terdiri atas obyek atau subyek yang mempunyai karakteristik dan kualitas tertentu yang ditetapkan oleh peneliti untuk diteliti kemudian ditarik kesimpulannya. ${ }^{10}$

Populasi adalah wilayah generalisasi yang terdiri atas obyek/subyek yang mempunyai kuantitas dan karakteristik tertentu yang ditetapkan oleh peneliti untuk dipelajari, dan kemudian ditarik kesimpulannya. ${ }^{11}$

Dalam penelitian ini, terdapat dua populasi yaitu populasi 1 terdiri dari peserta didik alumni SMP kelas X IPS dan X Bahasa SMA Negeri 1 Palu, dan populasi 2 adalah peserta didik alumni MTs kelas X IPS dan X Bahasa SMA Negeri 1 Palu.

\section{Sampel}

Sampel adalah bagian dari populasi yang diambil melalui cara-cara tertentu yang juga memiliki kekhasan tertentu, jelas dan lengkap yang dianggap bisa mewakili populasi. ${ }^{12}$

Dalam penelitian ini terdapat dua sampel yang disesuaikan dengan populasi. Terdiri dari dua yaitu peserta didik alumni SMP dan peserta didik

\footnotetext{
${ }^{11}$ Sugiyono, Metode Penelitian Pendidikan, (Ed.3, Cet. 1; Bandung: Alfabeta, 2019), 145

${ }^{12}$ Danu Eko Agustinova, Memahami Metode Penelitian Kualitatif, (Cet. I; Yogyakarta: Calpulis, 2015), 53.
} 
alumni MTs. Khusus untuk penentuan sampel peserta didik alumni MTs, dikarenakan jumlah populasi yang sangat kecil yaitu berjumlah 12 peserta didik maka digunakan teknik penarikan sampel jenuh yaitu $\sum$ sampel $=\sum$ populasi. Adapun sampel peserta didik alumni SMP karena peserta didiknya berjumlah 199 dan berbanding jauh dari peserta didik alumni MTs yang hanya berjumlah 12 orang, maka dalam pengambilan sampel peserta didik alumni SMP akan menggunakan teori dari Suharsimi Arikunto (dalam Hermawan), “sampel adalah sebagian atau wakil populasi yang diteliti. Apabila subjeknya kurang dari 100 lebih baik diambil semua. Sebaliknya jika subjeknya lebih besar dari 100 dapat diambil antara $10-15 \%$ atau $20-25 \%$, atau lebih". ${ }^{13}$

Berdasarkan teori tersebut, penulis mengambil sampel sebesar 20,6\%, yaitu dengan penjabaran sebagai berikut:

$$
\text { sampel } \frac{20.6}{100} \times 199=40,994=41
$$

Dari hasil diatas dapat diketahui jumlah sampel peserta didik SMP yang akan digunakan adalah 41 peserta didik.

\footnotetext{
${ }^{13}$ Yoni Hermawan, "Hubungan Antara Tingkat Pendidikan Dan Persepsi Dengan Perilaku Ibu Rumah Tangga Dalam Pemeliharaan Kebersihan Lingkungan".

Bumi Lestari Journal of Environment, vol.5,
}

Kemudian untuk menarik sampel

dari 41 peserta didik alumni SMP, akan digunakan teknik Proportionate Stratified Random Sampling, dengan menggunakan rumus sebagai berikut: $n 1 \frac{p x n}{N}$

Keterangan :

$n_{1}=$ Jumlah sampel dari masingmasing program

$\mathrm{p}=$ Jumlah populasi dari masing-masing program

$\mathrm{n}=$ Keseluruhan sampel

$\mathrm{N}=$ Keseluruhan populasi

a. Program IPS 1 dengan jumlah keseluruhan 33 peserta didik, dimasukkan kedalam rumus

$$
n 1 \frac{33 \times 41}{199}=7 \text { Peserta didik }
$$

b. Program IPS 2 dengan jumlah keseluruhan 34 peserta didik, dimasukkan kedalam rumus

$$
n 1 \frac{34 \times 41}{199}=7 \text { Peserta didik }
$$

c. Program IPS 3 dengan jumlah keseluruhan 33 peserta didik, dimasukkan kedalam rumus

no.2 (November 2012). https://ojs.unud.ac.id/index.php/blje/issue/vi ew/393 (diakses 16 November 2019). 
Al Bariq : Jurnal Pendidikan Bahasa Arab, 1, (1), 2020, 34-51

$$
n 1 \frac{33 \times 41}{199}=7 \text { Peserta didik }
$$

d. Program IPS 4 dengan jumlah keseluruhan 32 peserta didik, dimasukkan kedalam rumus

$$
n 1 \frac{32 \times 41}{199}=6 \text { Peserta didik }
$$

e. Program IPS 5 dengan jumlah keseluruhan 34 peserta didik, dimasukkan kedalam rumus

$$
n 1 \frac{34 \times 41}{199}=6 \text { Peserta didik }
$$

f. Program X Bahasa dengan jumlah keseluruhan 33 peserta didik, dimasukkan kedalam rumus :

$$
n 1 \frac{33 \times 41}{199}=6 \text { Peserta didik }
$$

Hasil penarikan sampel dengan menggunakan Proportionate Stratified

Random Sampling diperoleh sampel dari masing-masing program yakni IPS 1

berjumlah 7 peserta didik, IPS 2 berjumlah 7 peserta didik, IPS 3 berjumlah 7 peserta didik, IPS 4

14 M. Djunaidi Ghony dan Fauzan Almanshur, Metodologi Penelitian Kualitatif. (Cet. III; Jogjakarta: Ar-Ruzz Media, 2016), 165. berjumlah 6 peserta didik, IPS 5 berjumlah 7 peserta didik, dan X Bahasa berjumlah 7 peserta didik, secara keseluruhan berjumlah 41 peserta didik. Dengan demikian sampel dari penelitian ini adalah berjumlah 53 peserta didik, 41 peserta didik alumni SMP dan 12 peserta didik alumni MTs.

d. Teknik Pengumpulan Data

Ada beberapa teknik yang penulis gunakan dalam pengumpulan data, yaitu sebagai berikut:

\section{Observasi}

Observasi merupakan sebuah tekhnik pengumpulan data yang mengharuskan peneliti turun ke lapangan mengamati hal-hal yang berkaitan dengan ruang, tempat, pelaku, kegiatan, bendabenda, waktu, peristiwam tujuan, dan perasan. Metode observasi merupakan cara yang sangat baik untuk mengawasi perilaku subjek penelitian seperti perilaku dalam lingkungan atau ruang, waktu dan keadaan tertentu. ${ }^{14}$ Dalam observasi ini 
Al Bariq : Jurnal Pendidikan Bahasa Arab, 1, (1), 2020, 34-51

akan mengungkapkan keadaan tempat

(letak geografis sekolah) serta

menggambarkan secara umum seperti apa

hasil belajar bahasa Arab peserta didik

kelas X IPS dan Bahasa di SMA Negeri 1

Palu.

\section{Dokumen}

Dokumen merupakan catatan peristiwa yang sudah berlalu. Dokumen bisa berbentuk tulisan, gambar, atau karya-karya monumental dari seseorang. ${ }^{15}$ Dokumen ditujukan untuk memperoleh data-data yang relevan dengan aspek-aspek dalam penelitian serta menunjang keberlangsungan dari sebuah penelitian. Adapun dokumen yang digunakan dalam penelitian ini adalah data hasil belajar peserta didik berupa nilai UTS bahasa Arab peserta didik kelas X IPS dan Bahasa SMA Negeri 1 Palu.

\section{Wawancara}

Wawancara atau interviu adalah suatu bentuk komunikasi verbal jadi

\footnotetext{
${ }^{15}$ Sugiyono, Metode Penelitian pendidikan.
} (Cet. 20; Bandung: Alfabeta, 2014), 329. semacam percakapan yang bertujuan memperoleh informasi. ${ }^{16}$ Metode ini dilakukan untuk menggali informasi dari peserta didik kelas X IPS dan Bahasa SMA Negeri 1 Palu yang menjadi sampel sebagai objek penelitian.

\section{e. Teknik Analisis Data}

Analisis data yang digunakan dalam penelitian ini adalah analisis kuantitatif, yaitu analisis yang pengelolaan datanya berupa angka-angka serta perhitungannya menggunakan rumus statistik dengan program computer yaitu SPSS.

Setelah semua data terkumpul, terdapat dua teknik analisis yang digunakan untuk menganalisis data angket hasil belajar yaitu:

\section{Analisis Deskriptif}

Menurut Ronald E. Walpole, statistika deskriptif adalah metodemetode yang berkaitan dengan pengumpulan dan penyajian suatu gugus data sehinggamemberikan informasi yang berguna. Statistika deskriptif hanya

\footnotetext{
${ }^{16}$ S. Nasution, Metode Research, (Ed. I; Cet;
} XIV; Jakarta: Bumi Aksara, 2014), 98. 
Al Bariq : Jurnal Pendidikan Bahasa Arab, 1, (1), 2020, 34-51

memberikan informasi mengenai data yang dipunyai dan sama sekali tidak menarik inferensia atau kesimpulan apapun tentang gugus induknya yang lebih besar. Dengan statistika deskriptif, kumpulan data yang diperoleh akan tersaji dengan ringkas dan rapi serta dapat memberikan informasi inti dari kumpulan data yang ada. ${ }^{17}$

Dalam penelitian ini data hasil belajar bahasa Arab dianalisis secara statistik deskriptif berdasarkan kriteria ketuntasan minimal (KKM) yang berlaku di SMA Negeri 1 Palu, sebagai berikut:

\section{Tabel. 3.1}

\section{Interpretasi Kategori Hasil Belajar} Bahasa Arab

\begin{tabular}{|c|c|c|}
\hline NO & Interval Skor & Kategori \\
\hline 1. & $90-100$ & Baik Sekali \\
\hline 2. & $80-89$ & Baik \\
\hline 3. & $76-79$ & Cukup \\
\hline 4. & $0-75$ & Kurang \\
\hline
\end{tabular}

2. Analisis Inferensial

Statistik inferensial adalah bagian statistik yang mempelajari

${ }^{17}$ Rachmat Trijono, Metodologi Penelitian Kuantitatif, (Jakarta: Papas Sinar Sinanti, 2015), 40.

${ }^{18}$ Iqbal Hasan, Analisis Data Penelitian Dengan Statistik, (Cet. 1; Jakarta: PT Bumi Aksara, 2004), 2. penafsiran dan penarikan kesimpulan yang berlaku secara umum dari data yang tersedia. ${ }^{18}$ Analisis inferensial penulis menggunakan analisis statistik non parametrik karena data yang digunakan adalah data nominal maupun ordinal yaitu hasil belajar berupa nilai bahasa Arab dari peserta didik alumni SMP dan alumni MTs. Dalam hal ini akan dilakukan uji 2 sampel bebas atau Two Independent Samples Tests untuk menguji perbandingan dua rata-rata kelompok sampel bebas.

Penulis akan menggunakan uji Mann-Whitney dengan bantuan program IBM SPSS Statictics. Dengan ketentuan jika signifikansi $<0,05$ maka Ho ditolak, jika signifikansi > 0,05 maka Ho diterima. ${ }^{19}$

\section{Hasil Penelitian dan Pembahasan \\ 1. Dokumen}

Dokumen yang digunakan dalam menyajikan hasil belajar bahasa Arab peserta didik diambil dari perolehan nilai UTS semester ganjil tahun pelajaran

\footnotetext{
${ }^{19}$ Duwi Priyatno, Belajar Cepat Olah Data Statistik dengan SPSS, (Yogyakarta: Andi, 2012), 111.
} 
Al Bariq : Jurnal Pendidikan Bahasa Arab, 1, (1), 2020, 34-51

2019/2020. Nilai UTS digunakan dalam

penelitian ini, karena peneliti melakukan

penelitian pada pertengahan semester

ganjil, dan hasil belajar bahasa Arab

terupdate yang tersedia adalah nilai UTS.

Adapun nilai UTS dari peserta

didik alumni SMP dan peserta didik

alumni MTs kelas X IPS dan Bahasa

SMA Negeri 1 Palu yang menjadi sampel dalam penelitian ini adalah sebagai berikut:

Tabel 4.10

Nilai UTS Peserta Didik Alumni SMP

Kelas X IPS dan Bahasa SMA Negeri 1

Palu

\begin{tabular}{|c|c|c|c|}
\hline NO & $\begin{array}{c}\text { INISIAL } \\
\text { PESERTA } \\
\text { DIDIK }\end{array}$ & KELAS & NILAI \\
\hline 1 & ASA & IPS 1 & 75 \\
\hline 2 & GY & IPS 1 & 80 \\
\hline 3 & MFHN & IPS 1 & 82 \\
\hline 4 & MYA & IPS 1 & 83 \\
\hline 5 & MAP & IPS 1 & 84 \\
\hline 6 & KC & IPS 1 & 85 \\
\hline 7 & SM & IPS 1 & 97 \\
\hline 8 & CLA & IPS 2 & 77 \\
\hline
\end{tabular}

\begin{tabular}{|c|c|c|c|}
\hline 9 & ADAP & IPS 2 & 79 \\
\hline 10 & MMLN & IPS 2 & 81 \\
\hline 11 & NS & IPS 2 & 82 \\
\hline 12 & $\mathrm{NAC}$ & IPS 2 & 83 \\
\hline 13 & $\mathrm{ZI}$ & IPS 2 & 84 \\
\hline 14 & ZDW & IPS 2 & 84 \\
\hline 15 & ARHN & IPS 3 & 75 \\
\hline 16 & HOKT & IPS 3 & 77 \\
\hline 17 & AKRN & IPS 3 & 79 \\
\hline 18 & RRFD & IPS 3 & 81 \\
\hline 19 & MRSK & IPS 3 & 83 \\
\hline 20 & $\mathrm{RKN}$ & IPS 3 & 85 \\
\hline 21 & VA & IPS 3 & 85 \\
\hline 22 & $\mathrm{BNS}$ & IPS 4 & 77 \\
\hline 23 & AMI & IPS 4 & 79 \\
\hline 24 & RW & IPS 4 & 82 \\
\hline 25 & APRWN & IPS 4 & $8 n 3$ \\
\hline 26 & RSK & IPS 4 & 84 \\
\hline 27 & NSYA & IPS 4 & 85 \\
\hline 28 & MAPRJT & IPS 5 & 77 \\
\hline 29 & MAV & IPS 5 & 78 \\
\hline 30 & RA & IPS 5 & 79 \\
\hline 31 & IRN & IPS 5 & 80 \\
\hline 32 & $\mathrm{PH}$ & IPS 5 & 81 \\
\hline 33 & SYP & IPS 5 & 82 \\
\hline 34 & HRM & IPS 5 & 83 \\
\hline 35 & DJ & X BAHASA & 77 \\
\hline 36 & $\mathrm{MC}$ & X BAHASA & 81 \\
\hline 37 & $\mathrm{ADP}$ & X BAHASA & 82 \\
\hline 38 & $\mathrm{AH}$ & X BAHASA & 82 \\
\hline 39 & MNA & X BAHASA & 83 \\
\hline
\end{tabular}


Al Bariq : Jurnal Pendidikan Bahasa Arab, 1, (1), 2020, 34-51

\begin{tabular}{|c|c|c|c|}
40 & DAM & X BAHASA & 84 \\
\hline 41 & AYP & X BAHASA & 85 \\
\hline
\end{tabular}

Tabel 4.11

Nilai UTS Peserta Didik Alumni MTs Kelas X IPS dan Bahasa SMA Negeri 1 Palu

\begin{tabular}{|c|c|c|c|}
\hline NO & $\begin{array}{c}\text { INISIAL } \\
\text { PESERTA }\end{array}$ & KELAS & NILAI \\
\hline 1 & MAP & IPS 1 & 84 \\
\hline 2 & ADV & IPS 1 & 78 \\
\hline 3 & RZ & IPS 1 & 83 \\
\hline 4 & NRSY & IPS 3 & 82 \\
\hline 5 & RH & IPS 3 & 82 \\
\hline 6 & DN & IPS 4 & 82 \\
\hline 7 & AR & IPS 4 & 79 \\
\hline 8 & MN & IPS 4 & 83 \\
\hline 9 & NHN & IPS 4 & 83 \\
\hline 10 & AAP & IPS 5 & 80 \\
\hline 11 & MZ & IPS 5 & 79 \\
\hline 12 & FR & X BAHASA & 85 \\
\hline
\end{tabular}

2. Wawancara

Wawancara dilakukan kepada 4 orang yang terpilih dari sampel dengan kriteria tertentu, yaitu 1 orang peserta didik alumni SMP peraih nilai UTS dalam kategori "Baik Sekali" dengan inisial

(SM), 1 orang peserta didik alumni SMP peraih nilai UTS dalam kategori "Baik" dengan inisial (LS), 1 orang peserta didik alumni MTs peraih nilai UTS dalam kategori "Baik" dengan inisial (MAP), dan 1 orang lagi peraih nilai UTS dalam kategori "Cukup" dengan inisial (ADV).

Berikut hasil kutipan wawancara kepada 4 orang peserta didik tersebut:

Tabel 4.12

\section{Daftar Pertanyaan dan Jawaban Wawancara}

\begin{tabular}{|c|c|}
\hline No. & Pertanyaan dan Jawaban \\
\hline 1. & $\begin{array}{l}\text { (-) Dimana asal sekolah sebelum } \\
\text { masuk SMA Negeri } 1 \text { Palu? }\end{array}$ \\
\hline & $\begin{array}{l}\checkmark \text { “..SMP Negeri } 1 \text { Palu." (SM) } \\
\checkmark \text { “..SMP Katolik Santo Paulus." } \\
\text { (LS) } \\
\checkmark \text { “..MTs Negeri } 1 \text { Kota Palu." } \\
\text { (MAP) } \\
\checkmark \text { “..MTs Negeri } 1 \text { Kota Palu." } \\
\text { (ADV) }\end{array}$ \\
\hline 2. & $\begin{array}{l}\text { (-) Apakah sebelum masuk di } \\
\text { SMA Negeri } 1 \text { Palu sudah } \\
\text { pernah belajar bahasa Arab } \\
\text { sebelumnya? } \\
\checkmark \text { “..kalau disekolah, belum. } \\
\text { Biasanya baca al-Qur'an saja.” } \\
\text { (SM) } \\
\checkmark \text { “..belum pernah." (LS) }\end{array}$ \\
\hline
\end{tabular}


Al Bariq : Jurnal Pendidikan Bahasa Arab, 1, (1), 2020, 34-51

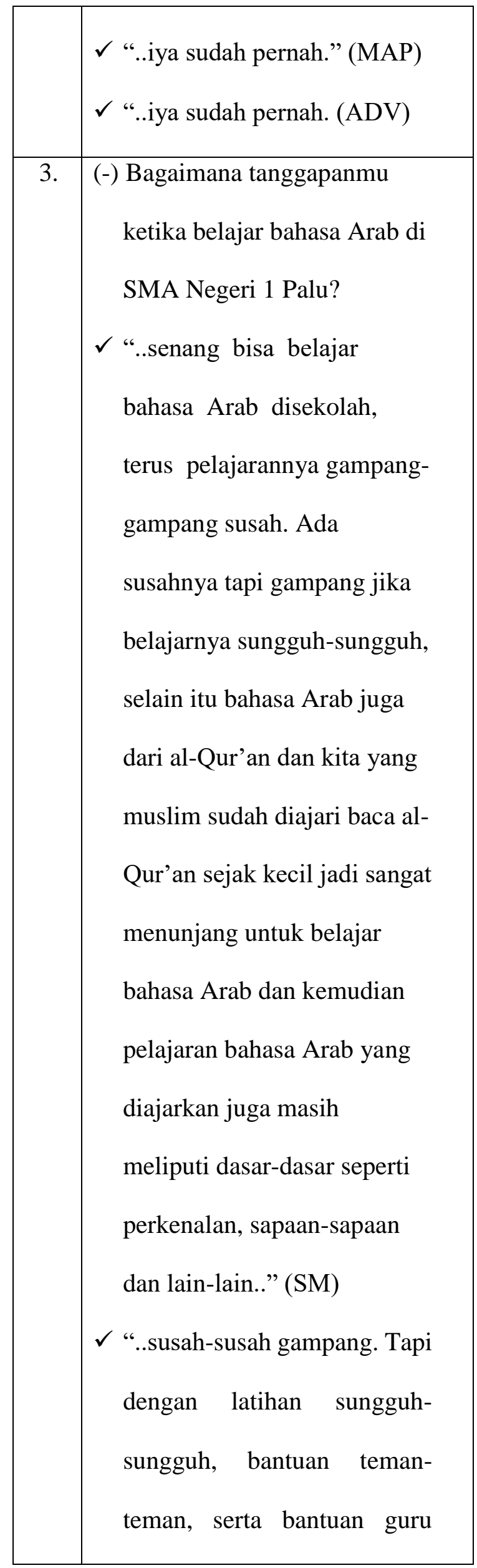

$\mid \begin{aligned} & \text { membimbing dengan cara } \\ & \text { mengajarkan cara } \\ & \text { membacanya dan menulisnya } \\ & \text { sehingga tidak terlalu } \\ & \text { mengalami kesulitan dalam } \\ & \text { mempelajari bahasa Arab. } \\ & \text { (LS) } \\ & \checkmark \text { “..sudah terbiasa hanya saja } \\ & \text { banyak yang sudah dilupa, } \\ & \text { tinggal diingat dan dipelajari } \\ & \text { kembali sekarang karena } \\ & \text { materinya masih sama belum } \\ & \text { jauh berbeda dari yang } \\ & \text { dipelajari sejak MTs.." } \\ & \text { (MAP) ..tanggapannya biasa saja } \\ & \text { mempelajari bahasa Arab di } \\ & \text { MTs, hanya saja tingkat } \\ & \text { (ADV) }\end{aligned}$

\section{Hasil Uji Analisis Statistik}

1. Analisis Statistik Deskriptif

Berdasarkan perolehan nilai

UTS bahasa Arab peserta didik

alumni SMP dan MTs kelas X IPS

dan X Bahasa SMA Negeri 1 Palu,

diperoleh informasi gambaran 
Al Bariq : Jurnal Pendidikan Bahasa Arab, 1, (1), 2020, 34-51

karakteristik distribusi skor nilai

bahasa Arab selengkapnya dapat

dilihat dari tabel berikut:

\begin{tabular}{|l|l|l|}
\hline Sum & 980 & 334 \\
& .0 & 5.0 \\
& & 0 \\
\hline
\end{tabular}

Tabel 4.13

\section{Deskripsi Perolehan Nilai Bahasa Arab} Peserta Didik

Alumni SMP dan Peserta Didik Alumni MTs di SMA Negeri 1

Palu

\begin{tabular}{|c|c|c|}
\hline & $\begin{array}{l}\text { ALUMNI } \\
\text { MTS }\end{array}$ & $\begin{array}{l}\text { ALUMNI } \\
\text { SMP }\end{array}$ \\
\hline Valid & 12 & 41 \\
\hline Missing & 29 & 0 \\
\hline Mean & 81.6667 & 81.5854 \\
\hline Std. Error of Mean & .63166 & .59261 \\
\hline Skewness & -.363 & 1.334 \\
\hline $\begin{array}{c}\text { Std. Error of } \\
\text { Skewness }\end{array}$ & .637 & .369 \\
\hline Kurtosis & -.925 & 5.681 \\
\hline $\begin{array}{c}\text { Std. Error of } \\
\text { Kurtosis }\end{array}$ & 1.232 & .724 \\
\hline Range & 7.00 & 22.00 \\
\hline Minimum & 78.00 & 75.00 \\
\hline Maximum & $\begin{array}{l}85 . \\
00\end{array}$ & $\begin{array}{l}97 . \\
00\end{array}$ \\
\hline
\end{tabular}

menggambarkan tentang distribusi

perolehan nilai bahasa Arab peserta didik

alumni SMP kelas X IPS dan X Bahasa

SMA Negeri 1 Palu mempunyai nilai

rata-rata 81,58 berada dalam kategori

baik sesuai dengan kriteria ketuntasan

minimal (KKM) yang berlaku di SMA

Negeri 1 Palu. Sedangkan perolehan nilai

bahasa Arab peserta didik alumni MTs

kelas X IPS dan X Bahasa SMA Negeri 1

Palu mempunyai nilai rata-rata 81,67

yang juga termasuk dalam kategori baik

sesuai dengan kriteria ketuntasan minimal

(KKM) yang berlaku di SMA Negeri 1

Palu. Dari kedua rata-rata antara peserta

didik alumni SMP dan peserta didik

alumni MTs memiliki nilai yang hampir

sama dan juga sama-sama berada dalam

kategori baik, sehingga secara deskriptif

tidak terdapat perbedaan yang signifikan

antara kedua nilai dari peserta didik 
Al Bariq : Jurnal Pendidikan Bahasa Arab, 1, (1), 2020, 34-51

alumni SMP dan peserta didik alumni MTs kelas X di SMA Negeri 1 Palu.

\section{Analisis Statistik}

Inferensial

Dalam analisis statistik inferensial akan dilakukan analisis statistik non parametrik yaitu uji 2 sampel bebas atau Two Independent Samples Tests digunakan untuk menguji perbandingan dua rata-rata kelompok sampel yang independen, dengan uji Mann-Whitney. Selengkapnya dapat dilihat dari tabel berikut:

Tabel 4.14

Test Statistics ${ }^{\text {a }}$ Mann-Whitney

\begin{tabular}{|c|c|}
\hline & HASIL BELAJAR \\
\hline $\begin{array}{c}\text { Mann-Whitney } \\
\mathrm{U}\end{array}$ & 237.500 \\
Wilcoxon W & 1098.500 \\
$\mathrm{Z}$ & -.182 \\
$\begin{array}{c}\text { Asymp. Sig. (2- } \\
\text { tailed) }\end{array}$ & .856 \\
& \\
\hline
\end{tabular}

Berdasarkan tabel 4.14 diatas, dengan menggunakan uji Mann-Whitney diperoleh nilai probabilitas (sig) $>0,05$ $(0,856>0,05)$ maka Ho diterima dan $\mathrm{Ha}$ ditolak yang berarti secara garis besar bahwa tidak terdapat perbedaan yang signifikan terhadap hasil belajar antara peserta didik alumni SMP dengan peserta didik alumni MTs dalam mata pelajaran Bahasa Arab kelas X di SMA Negeri 1 Palu.

Berdasarkan distribusi perolehan nilai bahasa Arab peserta didik alumni SMP yaitu mempunyai nilai rata-rata 81,58 dan peserta didik alumni MTs mempunyai perolehan nilai rata-rata 81,67 yang artinya keduanya memiliki nilai yang hampir sama karena berada pada kategori yang sama yaitu "Baik" dalam kriteria ketuntasan minimal (KKM) yang berlaku di SMA Negeri 1 Palu. Hal ini membuktikan hipotesis yang menyatakan, tidak terdapat perbedaan yang signifikan terhadap hasil belajar peserta didik alumni SMP dengan peserta didik alumni MTs dalam mata pelajaran Bahasa Arab kelas X di SMA Negeri 1 Palu.

Kemudian dengan nilai hasil belajar bahasa Arab peserta didik alumni 
Al Bariq : Jurnal Pendidikan Bahasa Arab, 1, (1), 2020, 34-51

SMP dan peserta didik alumni MTs yang diperoleh dari hasil UTS pada semester ganjil tahun pelajaran 2019/2020, dilakukan analisis statistik non parametrik yaitu uji 2 sampel bebas atau Two Independent Samples Tests yang digunakan untuk menguji perbandingan dua rata-rata kelompok sampel yang Independen, dengan uji Mann-Whitney, dan memperoleh nilai probabilitas $($ sig $)>0,05 \quad(0,856>0,05) \quad$ maka $\mathrm{Ho}$ diterima dan Ha ditolak.

Dengan diterimanya Ho dan tertolaknya Ha, maka secara garis besar bahwa tidak terdapat perbedaan yang signifikan terhadap hasil belajar peserta didik alumni SMP dengan peserta didik alumni MTs dalam mata pelajaran Bahasa Arab kelas X di SMA Negeri 1 Palu.

Hal ini sejalan dengan wawancara sebelumnya kepada 4 orang peserta didik yang dipilih untuk mewakili sampel, dan hasil wawancara menyatakan bahwa latar belakang pendidikan tidak berpengaruh secara signifikan terhadap hasil belajar bahasa Arab mereka karena terdapat faktor-faktor lain yang mempengaruhi serta menunjang hasil belajar bahasa Arab, diantarnya faktor internal dan faktor eksternal. Faktor internal yang mempengaruhi hasil belajar bahasa Arab yaitu pada aspek psikologis meliputi: inteligensi, sikap maupun minat. Sementara faktor internal pada aspek lingkungan sosial yang mempengaruhi hasil belajar bahasa Arab yaitu teman dan guru.

\section{Kesimpulan}

Berdasarkan analisis dan pembahasan dalam penelitian "perbandingan hasil belajar peserta didik alumni SMP dan MTs dalam mata pelajaran bahasa Arab kelas X di SMA Negeri 1 Palu" dapat disimpulkan bahwa tidak terdapat perbedaan hasil belajar bahasa Arab antara peserta didik alumni SMP dan peserta didik alumni MTs. Hal ini terlihat dengan tingkat signifikansi lebih dari 0,05. Adapun latar belakang pendidikan, tidak memiliki pengaruh yang signifikan terhadap hasil belajar bahasa Arab, karena terdapat faktor lain yang mempengaruhi, diantaranya faktor 
eksternal dan internal berupa inteligensi,

sikap, minat, teman maupun guru.

\section{Daftar Pustaka}

Agustinova, Danu Eko. Memahami Metode Penelitian Kualitatif. Cet. I; Yogyakarta: Calpulis, 2015.

Astri Iskandar Yanti. "Studi Komparasi Prestasi Belajar Bahasa Arab Antara Siswa Yang Memiliki Minat Belajar Bahasa Arab Tinggi Dengan Rendah kelas VII MTsN Yogyakarta 1". http://digilib.uin-suka.ac.id/2522/ (diakses 24 Mei 2019).

Baharuddin, Ismail. "Pesantren dan Bahasa Arab". Jurnal Thariqah Ilmiah, vol.01, no.01 (Januari 2014). http://jurnal.iainpadangsidimpuan.ac.id/index.php/TI/article /view/253/0 (diakses 13 November 2019).

Belakang Pendidikan dengan Keberhasilan Mahasiswa Pada Bidang Studi Keagamaan di Sekolah Tinggi Agama Islam Negeri (STAIN) Manado". Jurnal Iqra',vol. 3, no.1 (Januari-Juni 2009). http://journal.iainmanado.ac.id/index.php/JII/article/view/ 545 (diakses 16 November 2019).

Dahar, Ratna Wilis. Teori-Teori

Belajar dan Pembelajaran. Jakarta: Erlangga, 2011.

Departemen Agama RI, Almumayyaz Al-Qur'an Tajwid Warna, Transliterasi Per Kata, Terjemah Per Kata, Bekasi: Cipta Bagus Segara, 2014.

Dosen Sosiologi. "Pengertian Penelitian Kuantitatif, Ciri, dan Jenisnya Lengkap." BlogDosenSosiologi.com. http://dosensosiologi.com/pengertianpenelitian-kuantitatif-ciri-dan-jenisnyalengkap/. (17 Februari 2018), diakses pada tanggal 26 Agustus 2019.

Fahrurrozi, Aziz. "Pembelajaran Bahasa Arab : Problematika Dan Solusinya". Jurnal Pendidikan Bahasa
Arab dan Kebahasaaraban, vol. 1, no. 2

(Desember 2014). http://journal.uinjkt.ac.id/index.php/arabi yat/article/view/1137 (diakses 13 November 2019).

Ghony, M. Djunaidi dan Almanshur, Fauzan. Metodologi Penelitian Kualitatif. Cet. III; Jogjakarta: Ar-Ruzz Media, 2016.

Hamalik, Oemar. Proses Belajar Mengajar. Jakarta: PT. Bumi Aksara, 2001.

Hasan, Iqbal. Analisis Data Penelitian Dengan Statistik, Cet. 1; Jakarta: PT Bumi Aksara, 2004.

Hermawan, Yoni. "Hubungan Antara Tingkat Pendidikan Dan Persepsi Dengan Perilaku Ibu Rumah Tangga Dalam Pemeliharaan Kebersihan Lingkungan". Bumi Lestari Journal of Environment, vol.5, no.2 (November 2012).

https://ojs.unud.ac.id/index.php/blje/issu e/view/393 (diakses 16 November 2019).

Setyaningsih, Agus. "Prestasi Belajar Bahasa Arab Di Mts Ma'arif $\mathrm{Nu}$ 04 Tamansari Purbalingga (Studi komparasi siswa alumni MI dengan SD)",

http://repository.iainpurwokerto.ac.id/35 09/ (22 Mei 2019).

Slameto. Belajar Dan FaktorFaktor Yang Mempengaruhinya. Cet. IV; Jakarta:PT Rineka Cipta, 2003.

Sugiyono, Metode Penelitian Pendidikan, (Ed.3, Cet. 1; Bandung: Alfabeta, 2019.

Sugiyono, Metode Penelitian pendidikan. (Cet. 20; Bandung: Alfabeta, 2014)

Sujarweni, V. Wiratna. Metodologi Penelitian. Yogyakarta: Pustaka Baru Press, 2014.

Thobroni, Muhammad \& Mustofa, Arif. Belajar \& Pembelajaran. Cet. II; Jogjakarta: Ar-Ruzz Media, 2013. 
Al Bariq : Jurnal Pendidikan Bahasa Arab, 1, (1), 2020, 34-51

Thobroni, Muhammad. Belajar \& Pembelajaran Teori dan Praktik. Cet. I; Yogyakarta: Ar-Ruzz Media, 2015.

Trijono, Rachmat. Metodologi Penelitian Kuantitatif. Jakarta: Papas Sinar Sinanti, 2015.

Widodo, Cerdik Menyusun Proposal Penelitian Skripsi, Tesis dan Disertasi.

Jakarta: Yayasan Kelopak dan Magna Script, 2005.

Wiyani, Novan Ardy. Desain Pembelajaran Pendidikan. cet.II; Yogyakarta: Ar-Ruzz Media, 2014.

Zulhannan. Teknik Pembelajaran Bahasa Arab. Jakarta: Rajawali Pers, 2015. 